VASudeva, R., R. P. GunaGa and M. Hanumantha (2000): Non synchronous flowering in teak seed orchards - a cause for low fruit production. Paper presented in the National Symposium on Forestry towards $21^{\text {st }}$ century, Tamil Nadu, Agricultural University, Coimbatore, India.

Verma, S. K., V. K. Sharma and S. K. BaGchi (1989): The phenology of flowering of reciprocal $\mathrm{F}_{1}$ hybrids
(Eucalyptus citriodora Hook. x E. torelliana F.V. Mvell.), $\mathrm{F}_{2}$ and $\mathrm{F}_{3}$ segregates and parent species at New Forest, Dehra Dun. Annals of Forest 7, 120-124.

WeNDELL, J. F. and N. F. WeEden (1989): Visualization and interpretation of plant isozymes. Isozymes in Plant Biology 4, 5-45.

\title{
Gene exchange across a postglacial contact zone in Fraxinus excelsior $\mathrm{L}$.
}

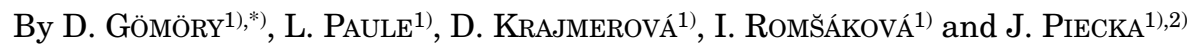

(Received $9^{\text {th }}$ March 2011)

\begin{abstract}
Hybridization between divergent lineages of common ash Fraxinus excelsior L. was studied in Slovakia and adjacent regions of Hungary, the Czech Republic and Poland in the contact zone between two postglacial colonization routes originating from different glacial refugia. Thirty-eight common ash populations were studied using a combination of 6 maternally inherited chloroplast microsatellite markers and 7 biparentally inherited nuclear microsatellites (nSSR). Two predominant chloroplast lineages were identified, between which the boundary was very sharp. Populations containing a mixture of different haplotypes were found only in the immediate proximity of the boundary. Bayesian analysis of population structure based on nSSR loci revealed the existence of two clusters, which largely coincided with chloroplast lineages. Both haplotype frequencies and proportions of clusters identified by the Bayesian analysis exhibited a clinal transition over the hybrid zone, with cline widths of $36 \mathrm{~km}$ for chloroplast haplotype frequencies (reflecting gene flow by seeds) and $275 \mathrm{~km}$ for Bayesian clusters based on nSSR (reflecting gene flow by pollen and seeds). Chloroplast haplotype diversity increased along the boundary between lineages not only because of admixture, but also due to the presence of rare haplotypes. In contrast, diversity at nuclear loci did not exhibit any geographical trend.
\end{abstract}

Key words: Fraxinus excelsior L., introgression, cline, postglacial colonization.

1) Technical University in Zvolen, TG Masaryka 24, SK-96053 Zvolen, Slovakia.

2) Lesy Bratislava, š.p., OLZ Smolenice, Trnavská 12, SK-919 04 Smolenice, Slovakia.

*) Corresponding author: Dr. DuŠAN GÖMÖRY. Technical University in Zvolen, TG Masaryka 24, SK-96053 Zvolen, Slovakia. Phone +421-45-5206226, Fax +421-45-5332654

E-Mail: gomory@vsld.tuzvo.sk

\section{Introduction}

Hybridization is commonly understood as crossing between individuals belonging to different species (MAlLet, 2005; RIESEBERG and CARNeY, 1998) or higher taxonomic units (many natural and artificial intergeneric hybrids exist in the Rosaceae, Brassicaceae, Poaceae, Orchidaceae etc., cf. RoBERTSON et al., 1991; ZwIERZYKowsKi et al., 1998). Nevertheless, gene exchange between infraspecific taxa represents, in principle, the same phenomenon. Even when the phenotypic differentiation between two populations is too small for them to be classified as different taxa, they may belong to different lineages, which, without mutual gene flow in the past, may have diverged genetically. Crosses between them may produce as contrasting results as crosses between closely related species (BURKE and ARNOLD, 2001; JOHANSEN-MoRRIS and LATTA, 2006). Offspring may be equivalent to parental lineages, exhibit heterosis or outbreeding depression. Hybrid vigour is mostly explained by overdominance or dominance, i.e. heterozygote advantage at some loci or suppression of recessive deleterious mutations that are expressed in the parental lineages (BIRCHLER et al., 2006). In the latter case, only F1 hybrids are superior to parents in viability or fertility, and hybrid breakdown occurs in later filial generations or backcrosses (JOHANSEN-MORRIS and LATTA, 2006; LATTA et al., 2007). The opposite phenomenon, outbreeding depression, is usually explained by incompatible interactions between nuclear genes (RosAS et al., 2010), cytonuclear interactions (SAMBATTI et al., 2008; ElLISON and BURTON, 2008) or, in later generations, by the breakdown of coadapted gene complexes through recombination (JOHANSEN-MORRIS and LATTA, 2006). Although opinion about the practical relevance of outbreeding depression varies, massive gene flow seems to threaten genetic integrity and decrease mean fitness 
of a plant population (BLEEKE et al., 2007; but see FRANKHAM, 2010), and recurrent hybridization or introgression may reduce mean fitness even where immigration rates are low (EDMANDS and TIMMERMAN, 2003). Information about the extent of gene flow between populations belonging to divergent lineages may thus be of practical relevance for nature conservation, forestry etc., even when there is no empirical proof of adaptive differentiation between them.

Long periods of isolation during glacial periods can lead to the establishment of such divergent lineages within species, including forest trees (HEwITT, 2000). During the glacial periods, tree populations were restricted to areas or locations called refugia where climates allowed survival and reproduction of species. Low population sizes and large distances separating important refugial areas (mainly southern European peninsulas) prevented gene flow and triggered differentiation, as documented by many neutral-marker-based studies (LiEPELt et al., 2002; MAGRI et al., 2006). Because neu- tral processes such as genetic drift or migration also affect adaptive genes, Quaternary glaciations must have left their traces also in those part of plant genomes which are subjected to natural selection.

Common ash (Fraxinus excelsior) is a wind-pollinated, predominantly outcrossing (BACLES et al., 2005) and wind-dispersed forest tree species. It is distributed over most of Europe and grows across a broad range of climates and soils (FRAXIGEN, 2005). Despite producing relatively heavy seeds, it has a strong colonization capacity. However, compared to some other broadleaves it is less competitive so it becomes a dominant species only on optimal sites. On most distribution maps, the range is shown as continuous (e.g., http://www.euforgen.org/ distribution_maps.html), but in fact the range is highly fragmented, broken into larger or smaller islands with questionable connectivity, at least in Central Europe (Atlas krajiny SR; http://enviroportal.sk/atlas/).

The reproductive system is complicated, the tree may have male, hermaphrodite or female flowers and the sex

Table 1. - Name, location and sample size of populations sampled.

\begin{tabular}{|c|c|c|c|c|}
\hline Population name & Abbreviation & Longitude & Latitude & Sample size \\
\hline \multicolumn{5}{|l|}{ Czech Republic } \\
\hline Křtiny & $\mathrm{KR}$ & $16^{\circ} 41^{\prime}$ & $49^{\circ} 19^{\prime}$ & 30 \\
\hline Šternberk, Vrapač & SV & $17^{\circ} 01^{\prime}$ & $49^{\circ} 43^{\prime}$ & 39 \\
\hline Vápenka & VA & $17^{\circ} 37^{\prime}$ & $48^{\circ} 52^{\prime}$ & 32 \\
\hline Strání & ST & $17^{\circ} 42^{\prime}$ & $48^{\circ} 50^{\prime}$ & 13 \\
\hline Bystřice pod Hostýnem & $\mathrm{BH}$ & $17^{\circ} 45^{\prime}$ & $49^{\circ} 22^{\prime}$ & 34 \\
\hline Ostrava, Svinov & OS & $18^{\circ} 12^{\prime}$ & $49^{\circ} 48^{\prime}$ & 34 \\
\hline Mionši & $\mathrm{MI}$ & $18^{\circ} 42^{\prime}$ & $49^{\circ} 39^{\prime}$ & 31 \\
\hline \multicolumn{5}{|l|}{ Slovakia } \\
\hline Píla & $\mathrm{PI}$ & $17^{\circ} 20^{\prime}$ & $48^{\circ} 24^{\prime}$ & 31 \\
\hline Chtelnica & $\mathrm{CH}$ & $17^{\circ} 38^{\prime}$ & $48^{\circ} 34^{\prime}$ & 30 \\
\hline Horná Súča & HS & $17^{\circ} 59^{\prime}$ & $48^{\circ} 58^{\prime}$ & 32 \\
\hline Duchonka & DU & $18^{\circ} 06^{\prime}$ & $48^{\circ} 40^{\prime}$ & 33 \\
\hline Horné Motešice & $\mathrm{HM}$ & $18^{\circ} 11^{\prime}$ & $48^{\circ} 50^{\prime}$ & 31 \\
\hline Nevidzany & NE & $18^{\circ} 28^{\prime}$ & $48^{\circ} 52^{\prime}$ & 33 \\
\hline Skýcov & SK & $18^{\circ} 30^{\prime}$ & $48^{\circ} 30^{\prime}$ & 30 \\
\hline Gader & GA & $18^{\circ} 58^{\prime}$ & $48^{\circ} 57^{\prime}$ & 18 \\
\hline Mláčik & ML & $19^{\circ} 01^{\prime}$ & $48^{\circ} 40^{\prime}$ & 33 \\
\hline L'ubochňa & LU & $19^{\circ} 09^{\prime}$ & $49^{\circ} 03^{\prime}$ & 35 \\
\hline Donovaly Hanesy & $\mathrm{DH}$ & $19^{\circ} 13^{\prime}$ & $48^{\circ} 53^{\prime}$ & 6 \\
\hline Kyslinky & KY & $19^{\circ} 24^{\prime}$ & $48^{\circ} 38^{\prime}$ & 32 \\
\hline Krivá nad Oravou & KO & $19^{\circ} 28^{\prime}$ & $49^{\circ} 17^{\prime}$ & 6 \\
\hline Horná Bzová & $\mathrm{HB}$ & $19^{\circ} 31^{\prime}$ & $48^{\circ} 32^{\prime}$ & 37 \\
\hline Habovka & $\mathrm{HA}$ & $19^{\circ} 42^{\prime}$ & $49^{\circ} 17^{\prime}$ & 4 \\
\hline Tisovec & $\mathrm{TI}$ & $19^{\circ} 46^{\prime}$ & $48^{\circ} 44^{\prime}$ & 40 \\
\hline Muránska planina & MU & $20^{\circ} 06^{\prime}$ & $48^{\circ} 47^{\prime}$ & 10 \\
\hline Kežmarské žlaby, Flak & $K Z$ & $20^{\circ} 19^{\prime}$ & $49^{\circ} 13^{\prime}$ & 31 \\
\hline Podsúlová, Dlhá dolina & PS & $20^{\circ} 30^{\prime}$ & $48^{\circ} 46^{\prime}$ & 30 \\
\hline Zamutov & $Z A$ & $21^{\circ} 33^{\prime}$ & $48^{\circ} 54^{\prime}$ & 30 \\
\hline Sobrance & so & $22^{\circ} 11^{\prime}$ & $48^{\circ} 45^{\prime}$ & 30 \\
\hline Jarabá skala & JA & $22^{\circ} 26^{\prime}$ & $49^{\circ} 06^{\prime}$ & 5 \\
\hline Zbojský potok & ZB & $22^{\circ} 29^{\prime}$ & $49^{\circ} 04^{\prime}$ & 29 \\
\hline \multicolumn{5}{|l|}{ Hungary } \\
\hline Kemence & $\mathrm{KE}$ & $18^{\circ} 58^{\prime}$ & $47^{\circ} 57^{\prime}$ & 29 \\
\hline Mátraszentimre & MS & $19^{\circ} 53^{\prime}$ & $47^{\circ} 54^{\prime}$ & 35 \\
\hline Lilafüred & $\mathrm{LI}$ & $20^{\circ} 37^{\prime}$ & $48^{\circ} 06^{\prime}$ & 32 \\
\hline Mogyoroske & MO & $22^{\circ} 20^{\prime}$ & $48^{\circ} 22^{\prime}$ & 29 \\
\hline \multicolumn{5}{|l|}{ Poland } \\
\hline Skomielna Biala & SB & $19^{\circ} 55^{\prime}$ & $49^{\circ} 39^{\prime}$ & 30 \\
\hline Losie & LO & $21^{\circ} 5^{\prime}$ & $49^{\circ} 33^{\prime}$ & 30 \\
\hline Czudec & $\mathrm{CZ}$ & $21^{\circ} 50^{\prime}$ & $49^{\circ} 56^{\prime}$ & 30 \\
\hline Brzegi Dolne & $\mathrm{BD}$ & $22^{\circ} 36^{\prime}$ & $49^{\circ} 26^{\prime}$ & 30 \\
\hline
\end{tabular}



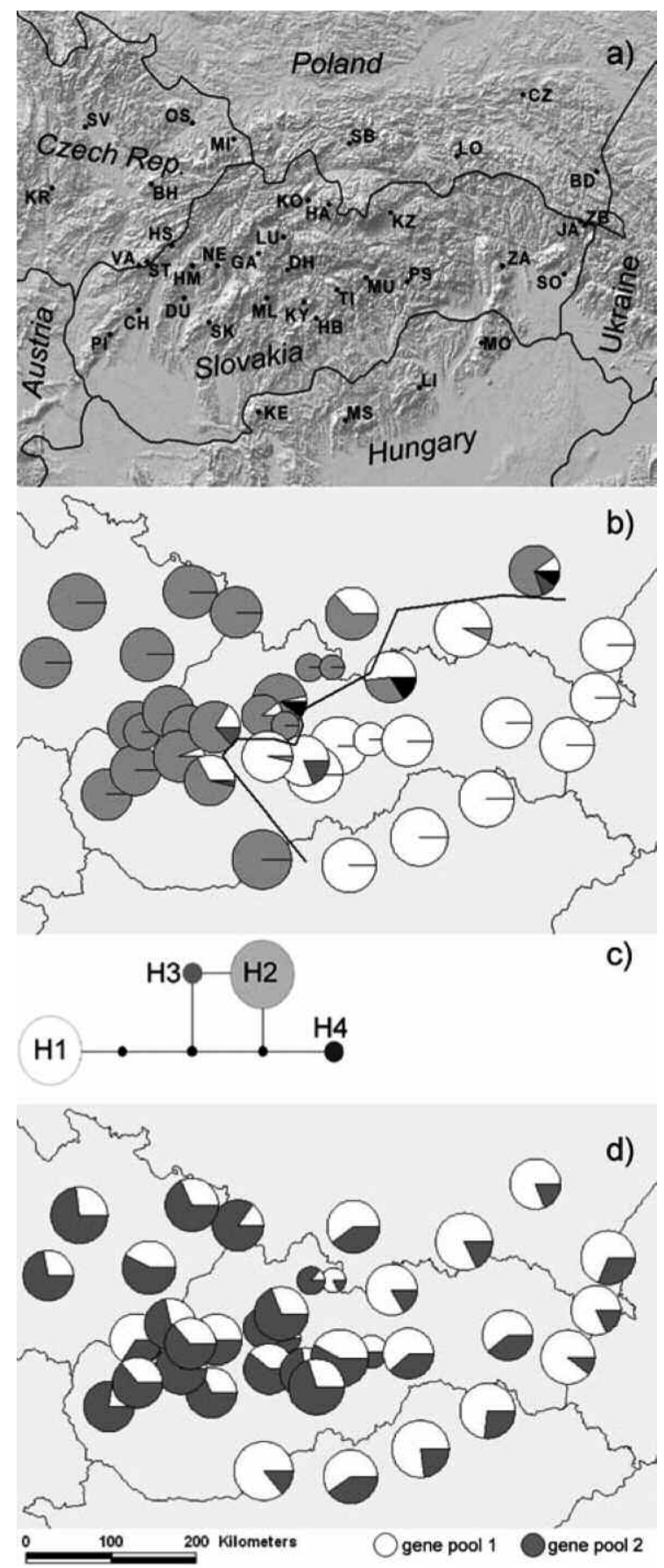

Figure 1. - Map of sampling locations of common ash populations (a), distribution of cpSSR haplotypes (b), statistical parsimony network of the cpSSR haplotypes (c), and proportions of gene pools based on the STRUCTURE analysis of nSSR genotypes $(d)$

function may range from pure males through all degrees of hermaphroditic intermediates to pure female individuals (FRAXIGEN, 2005). An extensive dieback caused by the fungus Chalarea fraxinea has been observed in Europe since the 1990s (KRAJ et al., 2012). Differences in timing and severity of the disease among different parts of the range may be associated with the dynamics of the spread, but also with differential, genetically determined susceptibility of local populations to the infection, associated with geographic origin (PLANTE and BERNIER, 1997).
Pollen records do not provide much information about the history of glacial survival and postglacial spread, as common ash pollen is generally only present in low percentages (excelsior-type pollen percentages rarely exceed $1 \%$ in older layers, cf. Fossil Pollen Database; http://pollen.cerege.fr/fp $\underline{\text { d-epd }}$ ). Both paleobotanical data (HUNTLEY and BIRKS, 1983) and genetic data (HEUERTZ et al., 2004a) suggest that the main glacial refugia for ash that contributed to the recolonization of central and Eastern Europe were located in the Balkans and the eastern Alps. A detailed mapping of chloroplast haplotype variation done by HEUERTz et al. (2004b) revealed that the boundary between the Eastern and CentralEuropean haplotypes runs from eastern Bosnia across central Slovakia towards northwestern Poland and the sea channels separating Denmark from Scandinavia. However, the relatively small sample sizes used by HEUERTZ et al. (2004b), ranging typically from 5 to 10 trees per population, do not allow the position of the dividing line to be determined precisely or the degree of gene-pool admixture across the contact zone to be assessed. The aim of the present study was to assess levels of admixture between lineages of common ash across the contact zone in Central Europe based on a larger sample size and assessment of the levels and spatial patterns of introgression between the lineages.

\section{Materials and Methods}

Thirty-eight putatively indigenous populations were sampled in Slovakia and adjacent regions of Hungary, the Czech Republic and Poland (Table 1, Fig. 1a). Mature leaves or twigs with dormant buds were collected typically from a minimum of 30 adult trees (aged over 80 years), but in few cases sample size was as low as 5 trees. Closed forests were sampled when available, but in few cases, trees growing on forest edges or in open landscape were sampled.

Total genomic DNA was extracted using a modified CTAB protocol following Doyle and Doyle (1987) from $10 \mathrm{mg}$ of silica-dried buds or leaves. DNA concentration was measured spectrophotometrically. Six and seven primer pairs were used for amplification of chloroplast (cpSSR) and nuclear (nSSR) microsatellite loci, respectively (Table 2). Fluorescent labeling of the forward primers allowed detection of amplification products on an automated DNA sequencer (ABI PRISM 3130, Applied Biosystems). The selected markers were amplified in three multiplex sets: (1) Femsatl4, Femsatl11, Femsatl16; (2) FR16, FR39, M2-30, FR41; (3) ccmp2, cстp3, ccmp10, ccmp4, ccmp6, ccmp7. The PCR reactions were set up in volumes of $10 \mu \mathrm{l}$ using Qiagen Multiplex PCR kit (Qiagen, 206143) with Q-solution. The PCR mixture was prepared according to manufacturer's instructions with approximately $10 \mathrm{ng}$ and $50 \mathrm{ng}$ of template DNA for chloroplast and nuclear microsatellites respectively. The concentration of each primer was $0.2 \mu \mathrm{M}$. The PCR profile for all reactions started with a denaturation step at $95^{\circ} \mathrm{C}$ for $15 \mathrm{~min}$, and finished with final extension at $60^{\circ} \mathrm{C}$ for $30 \mathrm{~min}$. The initial denaturation step was followed by 30 cycles of $30 \mathrm{~s}$ at $94^{\circ} \mathrm{C}, 45 \mathrm{~s}$ at $52^{\circ} \mathrm{C}$ and $60 \mathrm{~s}$ at $72^{\circ} \mathrm{C}$ for multiplex 1 . The cycle profile for multiplex 2 is 40 cycles of denaturation at $94^{\circ} \mathrm{C}$ 
Table 2. - Sequences and fluorescent labeling of microsatellite primers used.

\begin{tabular}{|c|c|c|c|}
\hline Sequence & Locus/Primer & Stain & Reference \\
\hline CGCACGTTCTTTCTATTTG & $\mathrm{M} 2-30 \mathrm{~F}$ & FAM & Brachet et al. (1999) \\
\hline GACCGGCTGACTATTTTCTC & $M 2-30 \mathrm{R}$ & & \\
\hline TTCATGCTTCTCCGTGTCTC & Femsatl4 F & FAM & Lefort et al. (1999) \\
\hline GCTGTTTCAGGCGTAATGTG & Femsat/4 R & & \\
\hline TTTAACAGTTAACTCCСTTC & Femsatl16 F & NED & Lefort et al. (1999) \\
\hline CAACATACAGCTACTAATCA & Femsatl16 R & & \\
\hline GATAGCACTATGAACACAGC & Femsatl11 F & VIC & Lefort et al. (1999) \\
\hline TAGTTCTACTACTTCAAGAA & Femsatl11 R & & \\
\hline CCTCTAGATAGTCGACTGG & FR16 F & VIC & Fraxigen (2005) \\
\hline САCTACACACTGCTTGAAAC & FR16 R & & \\
\hline AAATGGATGCGGCTAGGG & FR41 F & PET & Fraxigen (2005) \\
\hline ATTCCTGGGCCTCAAGAATA & FR41 R & & \\
\hline TGATGATCAACGGTATGAAT & $F R 39 \mathrm{~F}$ & NED & Fraxigen (2005) \\
\hline TGGCTTCAAAGATTTCCCTA & FR39 R & & \\
\hline GATCCCGGACGTAATCCTG & ccmp2 F & FAM & Weising and Gardner (1999) \\
\hline ATCGTACCGAGGGTTCGAAT & ccmp2 R & & \\
\hline CAGACCAAAAGCTGACATAG & cсmp3 F & FAM & Weising and Gardner (1999) \\
\hline GTTTCATTCGGCTCCTTTAT & ccmp3 R & & \\
\hline AATGCTGAATCGAYGACCTA & ccmp4 F & PET & Weising and Gardner (1999) \\
\hline CCAAAATATTBGGAGGACTCT & ccmp4 R & & \\
\hline CGATGCATATGTAGAAAGCC & ccmp6 F & PET & Weising and Gardner (1999) \\
\hline CATTACGTGCGACTATCTCC & ccmp6 R & & \\
\hline CAACATATACCACTGTCAAG & $c c m p 7 \mathrm{~F}$ & PET & Weising and Gardner (1999) \\
\hline ACATCATTATTGTATACTCTTTC & ccmp7 R & & \\
\hline TTTTTTTTTAGTGAACGTGTCA & ccmp10 F & FAM & Weising and Gardner (1999) \\
\hline TTCGTCGDCGTAGTAAATAG & ccmp10 R & & \\
\hline
\end{tabular}

for $45 \mathrm{~s}$, annealing at $53^{\circ} \mathrm{C}$ for $45 \mathrm{~s}$, and extension at $72^{\circ} \mathrm{C}$ for $45 \mathrm{~s}$. The cycling conditions for the multiplex of chloroplast markers were 25 cycles of denaturation at $94^{\circ} \mathrm{C}$ for $60 \mathrm{~s}$, primer annealing at $50^{\circ} \mathrm{C}$ for $60 \mathrm{~s}$, and extension at $72^{\circ} \mathrm{C}$ for 60 seconds.

Fragment analysis was performed on ABI PRISM 3130 genetic analyzer with GeneMapper 4.0. from Applied Biosystems by comparison with an internal sizing standard (GeneScan ${ }^{\mathrm{TM}} 500 \mathrm{LIZ}^{\circledR}$ ).

A model-based clustering procedure following PRITCHARD et al. (2000) was used to analyze the nSSR data. The program STRUCTURE (PRITCHARD et al., 2000) was run 10 times for each $K=1-10$, with a burn-in period of 200000 and 1000000 subsequent iterations without prior information on the population of origin to determine the number of clusters. The optimum number of clusters was determined using the procedure of EvANNo et al. (2005). Similarity among runs was calculated according to ROSENBERG et al. (2002), which allowed an assessment of whether the solutions obtained for each $K$ were consistent. The run with the highest posterior probability at the optimum $K$ was selected for interpretation. We assumed that gene exchange had occurred among populations from different origins and therefore we used the admixture model to estimate the fraction of the genome that each individual draws from each cluster, using sampling locations as prior information to assist the clustering. The fractions of the gene pools of both clusters were subsequently averaged over individuals within populations. STRUCTURE runs were carried out at the Bioportal of the University of Oslo (http://www.bioportal.uio.no).

A parsimony network was constructed to determine phylogenetic relationships among the cpSSR haplotypes using the program TCS v.1.21 (CLEMENT et al., 2000). Distances between haplotypes were determined as the sums of the absolute nucleotide-number differences between the haplotypes.

Chloroplast haplotype frequencies and proportions of gene pools determined by the STRUCTURE procedure in individual populations were mapped using ArcView 3.2 (ESRI, Redlands, USA). Both types of genetic data exhibited clinal variation. The chloroplast data indicated the existence of two maternal lineages (haplotypes $\mathrm{H} 1$ and $\mathrm{H} 2$; see Fig. $1 b$ ) putatively associated with different glacial refugia and occupying geographically continuous areas. The boundary between the lineages was determined as the line connecting the midpoints between neighbouring populations belonging predominantly to different lineages, such that the distance of the midpoint from the population centers was weighted by the frequencies of the respective haplotypes:

$$
d\left(P_{1}, P_{2}\right)\left(p_{1}+p_{2}\right)=d\left(P_{1}, M\right) p_{1}+d\left(P_{2}, M\right) p_{2}
$$

where $d\left(P_{1}, P_{2}\right)$ is the distance between the populations $P_{1}$ and $P_{2}, d\left(P_{1}, M\right)$ and $d\left(P_{2}, M\right)$ is the distance between the midpoint and the populations $P_{1}$ and $P_{2}$, respectively, and $p_{1}$ and $p_{2}$ are the frequencies of the haplotype 1 in $P_{1}$ and the haplotype 2 in $P_{2}$, respectively. As both the chloroplast and nuclear markers were likely to be selectively neutral, the observed clines were assumed to reflect the effects of migration and isolation by distance, rather than adaptation. Therefore, they do not follow linear geographic or environmental gradients but instead reflect curvilinear colonization routes from different glacial refugia. We expressed the cline by the distances of the analyzed populations from the line dividing chloroplast lineages (for populations situated west 
Table 3. - Allele sizes (bp) at cpSSR loci and their haplotype combinations in the investigated common ash populations.

\begin{tabular}{cccccccc}
\hline Haplotype & $c c m p 2$ & $c c m p 3$ & $c c m p 4$ & ccmp6 & ccmp7 & ccmp10 & Frequency \\
\hline H1 & 190 & 93 & 139 & 97 & 117 & 100 & 0.459 \\
H2 & 190 & 93 & 139 & 99 & 116 & 101 & 0.516 \\
H3 & 190 & 93 & 139 & 99 & 116 & 100 & 0.014 \\
H4 & 190 & 93 & 139 & 98 & 117 & 101 & 0.011 \\
\hline
\end{tabular}

and northwest of the boundary, distances were taken as negative, for the others as positive). Subsequently, haplotype frequencies and gene pool proportions were plotted against distance and least-square fitted to the sigmoid function to estimate the centre and the width of the cline (SZYMURA and BARTON, 1986):

$$
p=p_{1}+\left(p_{2}-p_{1}\right)\left[0.5+\tanh \left(\frac{d-c}{w}\right)\right]
$$

where $d$ is the distance of a population from the centre of the cline $(c), w$ is the width of the cline, and $p_{1}$ and $p_{2}$ are haplotype or STRUCTURE-group frequencies within the western and the eastern lineage, respectively. Rates of gene dispersal by seeds and pollen were estimated under the assumptions of isotropic dispersal and selective neutrality of the studied loci from cline width according to BARTON and HEWITT (1985):

$$
\sigma=\frac{w^{2}}{2 \pi T}
$$

where $\sigma$ is the dispersal rate and $T$ is time (generations).

Gene diversity for both chloroplast and nuclear microsatellite data was calculated as the mean number of pairwise differences between populations (NEI and LI, 1979; Pons and PETIT, 1996) using ARLEQUIN v.2.000. The diversity distribution along the longitudinal gradient (distances from the meeting line) was modeled using the Gaussian curve:

$$
p=p_{\min }+\left(p_{\max }-p_{\min }\right) \frac{\mathrm{e}^{-[(d-c) / \sigma]^{2}}}{\sigma \sqrt{2 \pi}}
$$

where $p_{\min }$ and $p_{\max }$ are the minimum and maximum diversity levels, respectively, $d$ is as above, $c$ is the location where diversity attains maximum (center of the diversity peak), and $\sigma$ is the standard deviation (related to the width of the diversity peak).

The coefficient of differentiation $\left(R_{S T}\right.$; taking into account allele size) (SLATKIN, 1995) was calculated using ARLEQUIN v.2.000 (SCHNEIDER et al., 2000). For the identification of recent reductions of effective population size, we used the methodology of LUIKART et al. (1998) based on comparison of the observed gene diversity and the gene diversity expected under mutation-drift equilibrium. Estimations under the two-phase mutation model were done using the program Bottleneck (CoRNUET and LUIKART, 1996).

\section{Results}

The chloroplast microsatellites used in this study were mononucleotide repeats (WEISING and GARDNER, 1999). We found variation at the following loci: ccmp6 (3 frag-
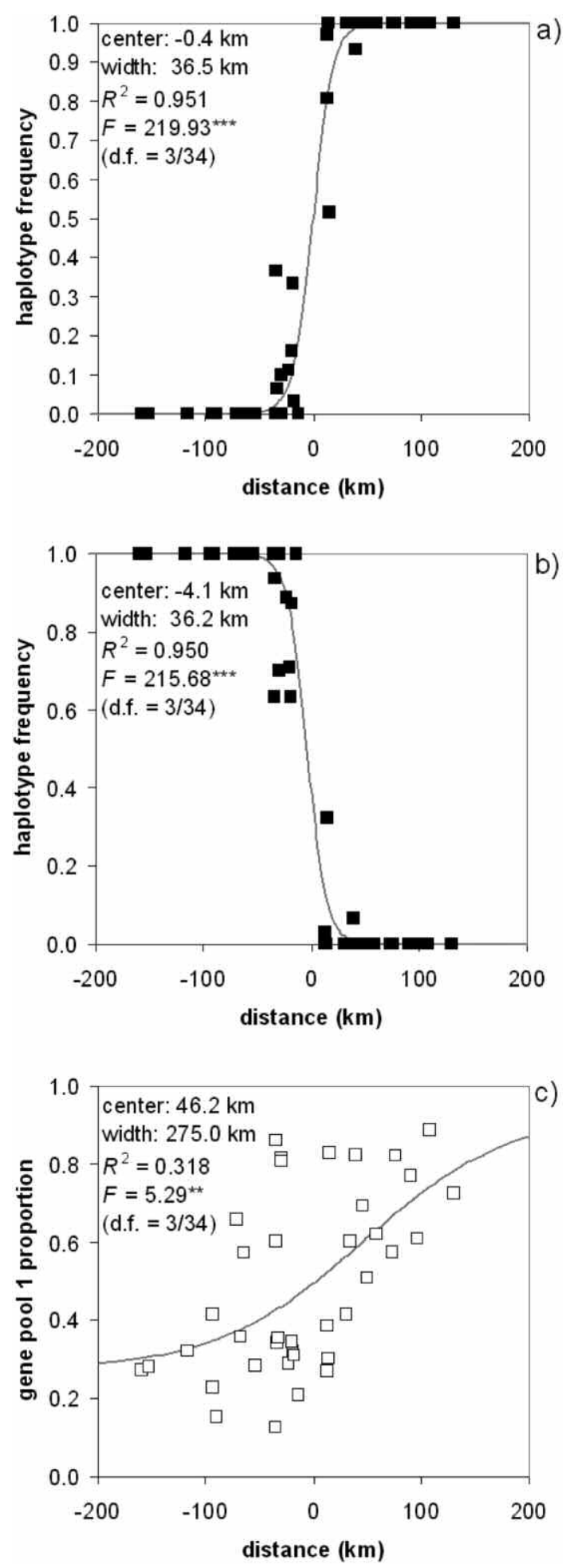

Figure 2. - Frequencies of cpSSR haplotypes H1 (a), H2 (b) and proportions of gene pools based on the STRUCTURE analysis of nSSR genotypes (c) fitted to the sigmoid curve in the study populations. 


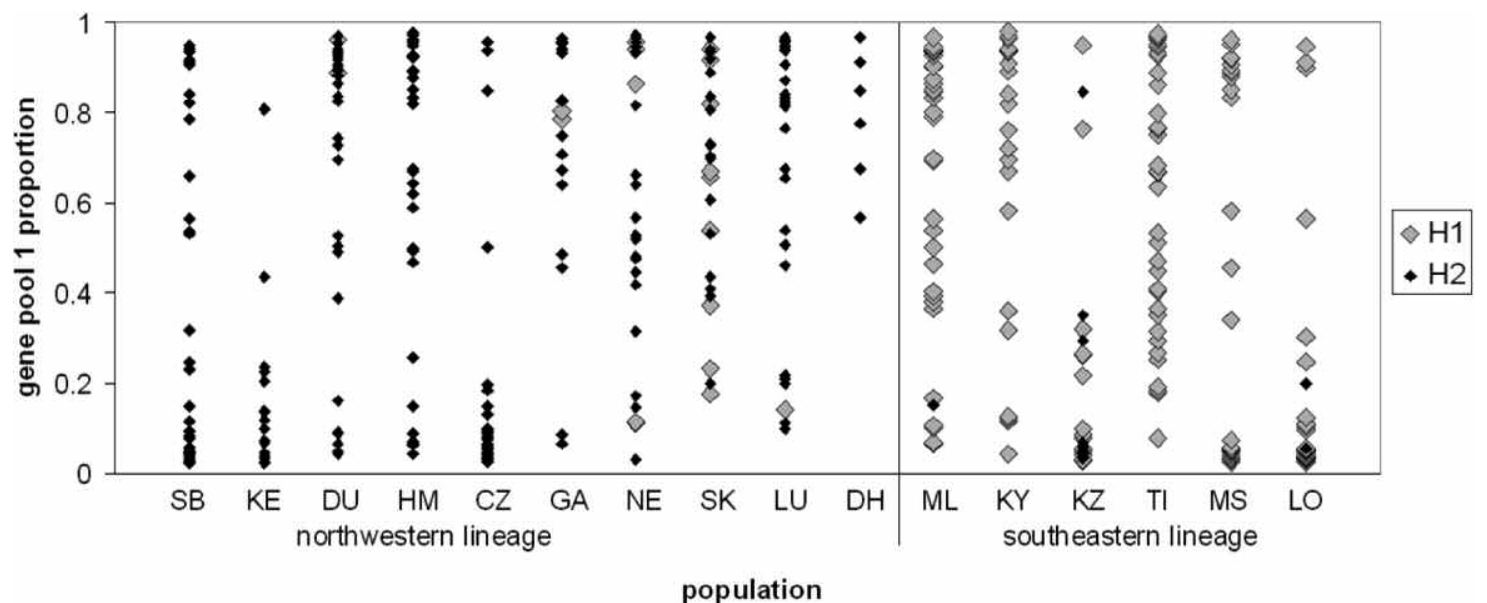

Figure 3. - Ancestries of individual trees with cpSSR haplotypes H1 and H2 inferred by STRUCTURE in the contact zone (populations adjacent to the meeting line). Populations are sorted according to the distance from the meeting line (West to East). For population acronyms, see Table 1.

ment-size variants differing by $1 \mathrm{bp}), \operatorname{ccmp} 7$ (2 variants, $1 \mathrm{bp}$ difference) and ccmp10 (2 variants, $1 \mathrm{bp}$ difference). The three remaining loci were monomorphic, with allele sizes of 190, 93 and 139 bp for ccmp2, ccmp3 and ccmp4, respectively. Alleles combined to produce four chloroplast haplotypes (Table 3). Two of the haplotypes were very common and represented $46 \%$ and $52 \%$ of trees, respectively. Their distribution was geographically structured: haplotype H1 was distributed more or less east of the $19^{\circ} 30^{\prime}$ meridian, haplotype $\mathrm{H} 2$ generally west of this line. Haplotypes H3 and H4 were rare ( 1\% each) and did not show any geographic structure.

Maternal lineages probably associated with different glacial refugia were thus largely determined by the two common haplotypes. The boundary between the ranges of both chloroplast lineages was quite sharp, although curvilinear (Fig. 1b). Along the boundary several populations contained both haplotype 1 and 2 , but the ranges of both lineages were continuous. The dividing line between lineages followed natural boundaries, suggesting that the orientation of mountains and valleys played an important role in migration. The boundary runs through central Slovakia and continues towards the northeast in accord with the orientation of most mountain ranges in the westernmost part of the Carpathians. The western lineage succeeded in migrating quite far towards the East along the northern Carpathian hillside. The eastern lineage apparently migrated along the whole Carpathian arc and also colonized isolated mountain ranges in the northern part of the Great Hungarian Plain (Fig. 1b).

Haplotype frequencies clearly exhibited a clinal trend, more or less in the direction of longitude. For both major lineages, the centre of the cline was located very close to the boundary $(-0.4 \mathrm{~km}$ and $-4.1 \mathrm{~km}$ for haplotypes $\mathrm{H} 1$ and $\mathrm{H} 2$, respectively), hence for both the cline width was almost identical, $36 \mathrm{~km}$ (Fig. $2 a, b$ ).

Inter-population differentiation at nuclear loci was moderate, considering the geographical scale of the study $\left(R_{S T}=0.0367\right)$. On the other hand, strong differentiation was found at the chloroplast loci $\left(R_{S T}=0.9488\right)$.
Using STRUCTURE, the $\Delta K$ measure (EvANNo et al., 2005) and the similarity coefficient (ROSENBERG et al., 2002) indicated $K=2$ as the most probable number of clusters, which was fully consistent with the chloroplast data.

The geographical distribution of gene pool proportions under the 2 cluster scenario partly reflects the distribution of maternal lineages (Fig. 1d). In general, one gene pool predominated in populations in central and eastern Slovakia, whereas the other was most common in populations in the Czech Republic and western Slovakia. The biggest discrepancies were observed in the populations bordering the meeting line.

Again, we observed a clinal transition of the proportions of both gene pools (Fig. 2c), although the dispersion of nSSR data around the sigmoid curve was much bigger than in the case of chloroplast data $\left(R^{2}=0.318\right.$ only). The centre of the cline was located to the east of the boundary $(+46.2 \mathrm{~km})$ and the cline was much broader $(275 \mathrm{~km})$.

Greater dispersion was observed at the individual level (Fig. 3). In each population, the inferred ancestries of individual trees ranged almost from 0 to 1. Fig. 3 does not indicate any obvious association of inferred ancestry with the chloroplast haplotype. However, trees belonging to the eastern lineage (H1) tended to have a generally lower proportion of gene pool 2 than trees with haplotype H2 $(0.400 \pm 0.359$ and $0.599 \pm 0.348$, respectively, Student's $t=0.891, P<0.0001,996$ d.f.). This was also true for the subset of populations in the narrow contact zone, adjacent to the meeting line $(0.412 \pm 0.366$ and $0.546 \pm 0.357$, respectively, $t=3.01, P=0.0028,274$ d.f.).

Haplotypic diversity clearly increased in populations located in the neighbourhood of the boundary. The observed data were fitted to the Gaussian curve, with a moderate goodness of fit $\left(R^{2}=0.273\right)$. The peak of diversity was located very close to the boundary $(-2.6 \mathrm{~km})$ and was very narrow $(\sigma=4.6 \mathrm{~km})(F i g .4 a)$. On the other hand, no trend of diversity was observed for nSSR data (Fig. 4b), diversity was quite uniformly distributed along the longitudinal gradient. 

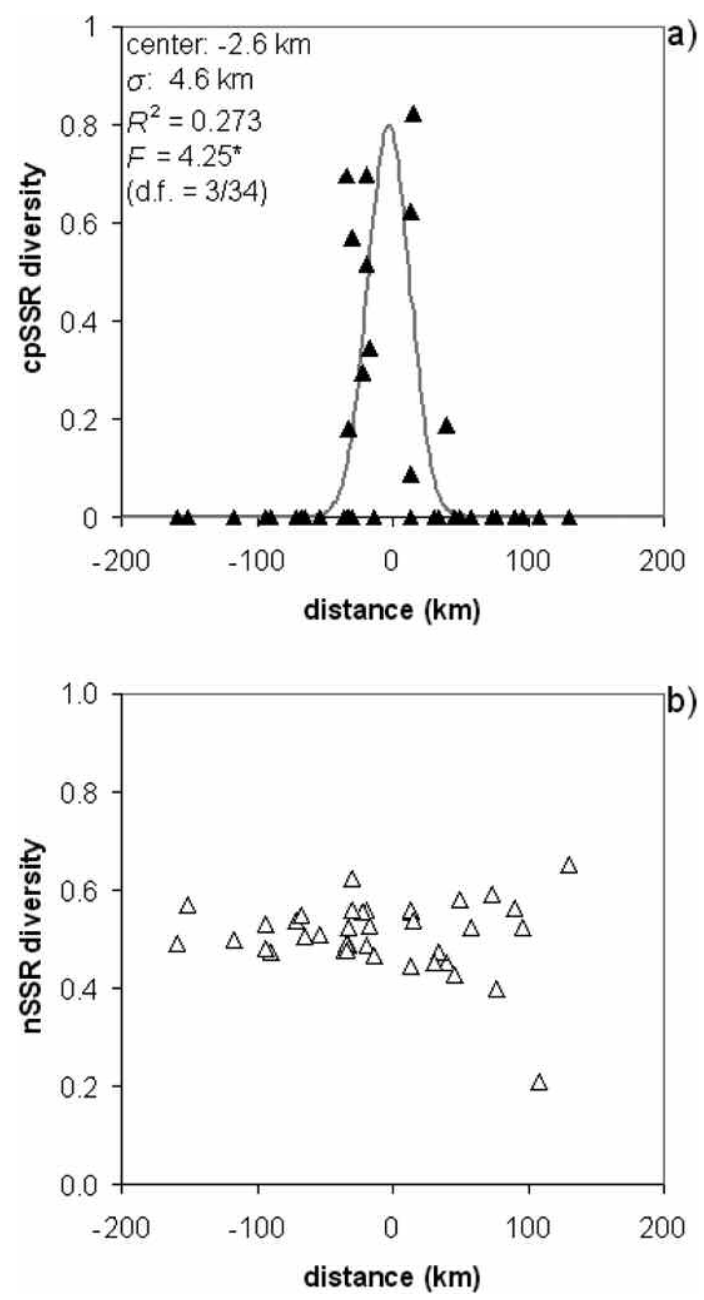

Figure 4. - Distribution of haplotype diversity fitted to the Gaussian function (a) and distribution of gene diversity at nSSR loci (b) along the gradient of distance from the boundary between maternal lineages.

No recent population bottlenecks were identified. Populations tended to exhibit heterozygosity deficiency rather than excess compared to mutation-drift equilibrium expectations (data not shown).

\section{Discussion}

Allele sizes at chloroplast microsatellite loci were not identical with the studies of HEUERTz et al. (2004a) or FRAXIGEN (2005). Generally, our estimates of fragment sizes were 1 to $4 \mathrm{bp}$ shorter, depending on locus. These differences may be technical, due to variation among the types of sequencers, polymers, fluorescence dyes, size standards or multiplex PCR kits used. We did not sequence the PCR products, fragment sizes were only determined by comparison with size standards according to sequencer manufacturer's recommendations, so that allele sizes were probably underestimated in most cases. Nevertheless, the differences seemed to be fully consistent among haplotypes. The two most frequent haplotypes (H1 and $\mathrm{H} 2$ ) showed consistent size differences at individual loci compared to the haplotypes H01 and H02 of Heuertz et al. (2004a). Similarly, the two rare haplotypes, $\mathrm{H} 3$ and $\mathrm{H} 4$, correspond to $\mathrm{H} 03$ and $\mathrm{H} 04$ from HEUERTZ et al. (2004a).

Due to substantially increased sample sizes, we were able to localize the boundary between maternal lineages and the degree of admixture more precisely than in previous studies, although there were no substantial discrepancies. We confirmed the presence of the CentralEuropean haplotype (H02) in southeastern Poland close to the Ukrainian border as found by HEUERTZ et al. (2004a), strongly indicating that this occurrence has not originated from incidental human transfer of ash reproductive material but is there as a result of natural migration. The fact that the Central-European lineage succeeded in penetrating so far to the east, slipping along the hillside bordering the Carpathians from the North, underlines the importance of topography in colonization processes of forest trees.

Although the boundary between chloroplast lineages was not a straight line, the distributions of the two lineages were continuous. Admixture with "alien" haplotypes was rare and limited to populations at the boundary. Mixed populations in which the most common haplotype was present in less than $70 \%$ of the tested trees were observed in only four cases, all remaining populations were either monotypic or contained only a small proportion of trees (less than 10\%) with a haplotype of the "alien" lineage. Unlike FRAXIGEN (2005), we did not observe alternating patches of populations belonging to different lineages. However, it is questionable whether the sample sizes used by FRAXIGEN (2005) (as few as 6 trees per population) really allow identification of population identity and admixture patterns. Our observation was in sharp contrast to haplotype distribution patterns in bird-dispersed tree species such as the Fagaceae, where the contact zones between Holocene colonization routes are generally much broader and contain a mosaic of haplotypes produced by long-distance dispersal events (PETIT et al., 2002). Such a mosaic might also be expected to develop in common ash because, in addition to stable populations on appropriate sites, it exhibits partial colonization/extinction dynamics, at least in the Carpathians. Our sample included populations which were supposed to have been formed recently by colonization of abandoned pastures and meadows. However, lack of evidence for population bottlenecks suggests that metapopulation dynamics plays only a minor role in the maintenance of the distribution range of ash.

Whereas the boundary between maternal lineages is sharp, gene flow by pollen over this boundary seems to be unhindered. In those populations which were far from the boundary, the frequencies of the eastern and western gene pools were concordant with the predominating chloroplast haplotype. However, discrepancies between the maternal lineage and gene pool proportions were observed in most populations located close to the boundary, suggesting most trees had acquired genetic material of the opposite lineage through introgression. Fat-tailed pollen dispersal curves have been reported for Fraxinus species, whereby pollen exchange is driven by population size rather than geographic distance, with 
larger populations acting predominantly as pollen donors, and smaller populations as pollen recipients (BACLES et al., 2005; BACLES and ENNOS, 2008). Isolated individuals or populations of one maternal lineage established within the range of the other (such as in northwest Hungary, central Slovakia or southeastern Poland) are thus expected to receive massive pollen flow from neighbouring populations.

Differences in dispersal distances result in contrasting cline widths for chloroplast and nuclear data, which differ by an order of 10 . They are also reflected in contrasting overall differentiation levels, which are congruent with earlier studies (HEUERTZ et al., 2004a, b).

Fossil pollen data indicate a relatively early arrival of ash species in Slovakia: Fraxinus pollen was found in high percentages at Slovak sites Regetovka and Liptovský Ján in layers dated 9000 BP (European Pollen Database; http://pollen.cerege.fr/fpd-epd). Common ash starts flowering and fruiting early, but in closed forests, generation turnover needs a minimum of $100-150$ years (KORPEL', 1995), which means that the time elapsed since the arrival corresponds to 60 to 90 generations. Applying the formula of BARTON and HEWITT (1985), this results in 130 to $200 \mathrm{~km}$ per-generation average dispersal distance for pollen and $2.3-3.4 \mathrm{~km}$ for seeds, assuming isotropic seed and pollen dispersal and neutrality of the markers used for the estimation of cline widths. Although HEUERTZ et al. (2003) reported strongly limited seed dispersal in $F$. excelsior, such a dispersal distance may be an underestimate. However, it applies to seeds penetrating territory where the species has already established, and where the density of newcomers is negligible compared to the density of local seeds.

The peak of haplotype diversity close to the boundary between lineages can be attributed not only to the combination of maternal lineages, but also to the occurrence of rare haplotypes. The presence of rare haplotypes is not surprising as such, they both occur commonly in Europe (H03 in the Alps, H04 in Spain and Great Britain; see HEUERTz et al., 2004a). Their presence far from their main distribution ranges has already been reported by HEBEL et al. (2005) and can be explained by human-mediated transfer of seeds or homoplasy (SUTHERLAND et al., 2010). What we cannot properly explain is why they are concentrated only in populations in the contact zone. We can exclude technical failure, as suspect samples were re-analyzed and allele sizes were confirmed.

Furthermore, technical problems would not account for the observation that rare haplotypes are not randomly distributed over the whole investigated area. Although we have not observed any sign of heteroplasmy in our material, we suggest ancient heteroplasmy associated with lineage crossing and subsequent recombination as a possible explanation for this phenomenon. Research in recent years has shown that organellar heteroplasmy is not as rare as previously supposed (FREY et al., 2005; WoLOSZYNSKA, 2010) and it was also observed in a related genus (Olea), although in an in vitro culture (GARCIA-DiAz et al., 2003). Ancient chloroplast recombination following interspecific hybridization was suggest- ed as an explanation for incongruent phylogenetic patterns between different regions of chloroplast genome in the Caryophyllaceae (ERIXoN and OxELman, 2008). A rather recent (Holocene) mitochondrial recombination was observed in the hybrid zone of Picea rubens and $P$. mariana (JARAMILLO-CORREA and BOUSQUET, 2005). Nothing is yet known about the extent of paternal leakage of cpDNA in Fraxinus, but if it occurs, it would only leave traces in contact zones between different chloroplast lineages. Naturally, this hypothesis requires explicit testing, but we think that it should not be rejected a priori.

From the practical point of view, it is primarily adaptive variation which is of interest. Unfortunately, there is no rangewide provenance experiment of common ash. Regional provenance trials testing usually local provenances against those originating from distant parts of the range have shown significant differences in fitnessrelated traits such as height growth, health condition or vegetative phenology, whereby the locals were not necessarily the best-performers (CUNDALL et al., 2003; PLIURA and BALIUCKAS, 2007). Our observations suggest that even if adaptive differentiation between maternal lineages existed, it would be wiped out by extensive gene flow in a broad zone along the boundary. No signs of outbreeding depression promoting the genetic integrity of maternal lineages were found, instead we observed extensive introgression between lineages already sharing most ancestral polymorphisms.

\section{Acknowledgements}

This study resulted from the project implementation: Centre of Excellence "Adaptive Forest Ecosystems", ITMS: 26220120006, supported by the Research and Development Operational Programme funded by the ERDF (50\%). The study was also supported by a grant of the Slovak Grant Agency for Science, VEGA $(1 / 0745 / 09)$.

\section{References}

BACles, C. F. E., J. BurczyK, A. J. Lowe and R. A. Ennos (2005): Historical and contemporary mating patterns in remnant populations of the forest tree Fraxinus excelsior L. Evolution 59: 979-990.

BACles, C. F. E. and R. A. EnNos (2008): Paternity analysis of pollen-mediated gene flow for Fraxinus excelsior L. in a chronically fragmented landscape. Heredity 101: 368-380.

Barton, N. H. and G. M. Hewitt (1985): Analysis of hybrid zones. Ann. Rev. Ecol. Syst. 16: 113-148.

Birchler, J. A., H. YAO and S. Chudalayandi (2006): Unraveling the genetic basis of hybrid vigor. Proc. Natl. Acad. Sci. USA 103: 12957-12958.

BleEke, W., U. SChmitz and M. Ristow (2007): Interspecific hybridisation between alien and native plant species in Germany and its consequences for native biodiversity. Biol. Cons. 137: 248-253.

Brachet, S., M. F. JubieR, M. RichaRd, B. Jung-Muller and N. Frascaria-Lacoste (1999): Rapid identification of microsatellite loci using 5 anchored PCR in the common ash Fraxinus excelsior. Mol. Ecol. 8: 160-163. 
Burke, J. M. and M. L. ARNOLD (2001): Genetics and the fitness of hybrids. Ann. Rev. Genet. 35: 31-52.

Clement, M., D. Posada and K. A. CRandall (2000): TCS: a computer program to estimate gene genealogies. Mol. Ecol. 9: 1657-1660.

CoRnuet, J. M. and G. LuIKart (1996): Description and power analysis of two tests for detecting recent population bottlenecks from allele frequency data. Genetics 144: 2001-2014.

Cundall, E. P., C. M. Cahalan and T. Connolly (2003): Early results of ash (Fraxinus excelsior L.) provenance trials at sites in England and Wales. Forestry 76: 385-399.

Doyle, J. J. and J. L. DoYLE (1987): A rapid DNA isolation procedure for small quantities of fresh leaf tissue. Phytochem. Bull. 19: 11-15.

Edmands, S. and C. C. Timmerman (2003): Modeling factors affecting the severity of outbreeding depression. Cons. Biol. 17: 883-892.

ELlison, C. K. and R. S. BuRTON (2008): Interpopulation hybrid breakdown maps to the mitochondrial genome. Evolution 62: 631-638.

ERIXON, P. and B. OXELMAN (2008): Reticulate or tree-like chloroplast DNA evolution in Sileneae (Caryophyllaceae)? Mol. Phylogen. Evol. 48: 313-325.

EvanNo, G., S. REgNAUT and J. Goudet (2005): Detecting the number of clusters of individuals using the software STRUCTURE: a simulation study. Mol. Ecol. 14: 2611-2620.

Felsenstein, J. (2002): PHYLIP (Phylogeny Inference Package) version 3.6a3. Department of Genome Science, University of Washington, Seattle.

FrankHAM, R. (2010): Challenges and opportunities of genetic approaches to biological conservation Biol. Cons. 143: 1919-1927.

FRAXIGEN (2005): Ash species in Europe: biological characteristics and practical guidelines for sustainable use. Oxford Forestry Institute, University of Oxford, Oxford.

Frey, J. E., B. FreY and D. ForCIOLI (2005): Quantitative assessment of heteroplasmy levels in Senecio vulgaris chloroplast DNA. Genetica 123: 255-261.

Garcia-Diaz, A., R. Oya, A. SANChez and F. Luque (2003): Effect of prolonged vegetative reproduction of olive tree cultivars (Olea europaea L.) in mitochondrial homoplasmy and heteroplasmy. Genome 46: 377-381.

Hebel, I., R. HAAS and A. Dounavi (2006): Genetic variation of common ash (Fraxinus excelsior L.) populations from provenance regions in southern Germany by using nuclear and chloroplast microsatellites. Silvae Genet. 55: $38-44$.

Heuertz, M., X. Vekemans, J. F. Hausman, M. Palada and O. J. HARDY (2003): Estimating seed versus pollen dispersal from spatial genetic structure in the common ash. Mol. Ecol. 12: 2483-2495.

Heuertz, M., S. Fineschi, M. Anzidei, R. PAstorelli, D. Salvini, L. Paule, N. Frascaria-Lacoste, O. J. Hardy, X. Vekemans and G. G. Vendramin (2004a): Chloroplast DNA variation and postglacial recolonization of common ash (Fraxinus excelsior L.) in Europe. Mol. Ecol. 13: 3437-3452.

Heuertz, M., J. F. Hausman, O. J. Hardy, G. G. VenDRAMin, N. Frascaria-Lacoste and X. VeKemans (2004b): Nuclear microsatellites reveal contrasting patterns of genetic structure between western and southeastern European populations of the common ash (Fraxinus excelsior L.). Evolution 58: 976-988.
HewitT, G. M. (2000): The genetic legacy of the Quaternary ice ages. Nature 405, 907-913.

Huntley, B. and H. J. B. BiRks (1983): An Atlas of Past and Present Pollen Maps for Europe, 0-13000 Years Ago. Cambridge University Press, Cambridge.

JARAmillo-Correa, J. P. and J. Bousquet (2005): Mitochondrial genome recombination in the zone of contact between two hybridizing conifers Genetics 171: 1951-1962.

Johansen-Morris, A. D. and R. G. LATTA (2006): Fitness consequences of hybridization between ecotypes of Avena barbata: Hybrid breakdown, hybrid vigor, and transgressive segregation. Evolution 60: 1585-1595.

KoRPEL', S̆. (1995): Die Urwälder der Westkarpaten. Gustav Fischer Verlag, Jena.

KRAJ, W., M. ZAREK and T. KowALSKI (2012): Genetic variability of Chalara fraxinea, dieback cause of European ash (Fraxinus excelsior L.). Mycol. Progress 11: 37-45.

LATTA, R. G., K. M. GARDNER and A. D. Johansen-MorRis (2007): Hybridization, recombination, and the genetic basis of fitness variation across environments in Avena barbata. Genetica 129: 167-177.

Lefort, F., S. Brachet, N. Frascaria-Lacoste, K. J. EDWARDS and G. C. Douglas (1999): Identification and characterisation of microsatellite loci in ash (Fraxinus excelsior L.) and their conservation in the olive family (Oleaceae). Mol. Ecol. 8: 1088-1091.

Liepelt, S., R. Bialozyt and B. Ziegenhagen (2002): Wind-dispersed pollen mediates postglacial gene flow among refugia. Proc. Natl. Acad. Sci. USA 99: 14590-14594.

Luikart, G., W. B. Sherwin, B. M. Steele and F. W. ALLENDORF (1998): Usefulness of molecular markers for detecting population bottlenecks via monitoring genetic change. Mol. Ecol. 7: 963-974.

Magri, D., G. G. Vendramin, B. Comps et al. (2006): Palaeobotanical and genetic data outline the Quaternary history of European beech populations. New Phytologist 171: 199-222.

MALLET, J. (2005): Hybridization as an invasion of the genome. Trends Ecol. Evol. 20: 229-237.

NEI, M. and W. H. Li (1979): Mathematical model for studying genetic variation in terms of restriction endonucleases. Proc. Natl. Acad. Sci. USA 76: 5269-5273.

Petit, R. J., S. Brewer, S. Bordács et al. (2002): Identification of refugia and post-glacial colonization routes of European white oaks based on chloroplast DNA and fossil pollen evidence. For. Ecol. Manage. 156: 49-74.

Plante, F. and L. BeRniER (1997): Variability of virulence of Nectria galligena towards northern hardwoods Eur. J. For. Pathol. 27: 261-272.

PliURA, A. and V. BALIUCKAS (2007): Genetic variation in adaptive traits of progenies of Lithuanian and western European populations of Fraxinus excelsior L. Baltic Forestry 13: 28-38.

Pons, O. and R. J. Petit (1996): Measuring and testing genetic differentiation with ordered versus unordered alleles Genetics 144: 1237-1245.

Pritchard, J. K., M. Stephens and P. Donnelly (2000): Inference of population structure using multilocus genotype data. Genetics 155: 945-959.

Rieseberg, L. H. and S. E. CARney (1998): Plant hybridization. New Phytologist 140: 599-624. 